\title{
Morphological peculiarities of fruits of the rare species Iris halophila Pall, I. pumila L. and I. hungarica Waldst. et Kit. (Iridaceae Juss.) in the conditions of introduction in the meadow-steppe cultural phytocenosis
}

\author{
느 V.V. Gritsenko
}

M.M. Gryshko National Botanical Garden, National Academy of Sciences of Ukraine, Timiryazevska str. 1, 01014 Kyiv, Ukraine; gritsenkoviktoria@gmail.com

Received: 27.01.2020 | Accepted: 23.05.2020 | Published: 30.06.2020

\begin{abstract}
The objective of this study was to analyze the morphological structure and to reveal common and distinguishing features of the fruit in rare steppe species Iris halophila, I. pumila and I. hungarica introduced in conditions of meadow-steppe cultural phytocenosis in the M.M. Gryshko National Botanical Garden, National Academy of Sciences of Ukraine (NBG).
\end{abstract}

Material and methods. Fruits of I. halophila, I. pumila and I. hungarica were collected on the botanicalgeographical plot "Steppes of Ukraine" of NBG during 2015-2019. Fruit parameters were measured using a regular ruler. Morphological terms are provided, according to Artyushenko \& Fedorov (1986). Colors were determined by Bondartsev's (1954) scale.

Results. In all analyzed species, the fruit is a trimeric and trilocular loculicidal capsule with multi-seeded locules. This capsule is erect, straight, leathery, glabrous, opening by dehiscence from top to bottom along the dorsal veins of carpels. The morphological peculiarities of the fruits, which may be additional diagnostic characters of these species, are established. In particular, in I. halophila capsule is cylindrical, with the upper part elongated into the apical spout (long, thin, bent to the side). The surface of I. halophila capsule is smooth, matte, six-ribbed. Ribs are located on both sides along each of the dorsal veins (i.e., along the dehiscence stria). The dehiscence is complete with diverging upper parts of the valves that remain connected just at the base. The capsule of I. pumila is ellipsoidal, with the upper part also elongated into the apical spout (short, thick, awl-shaped). The surface of I. pumila capsule is wrinkled, without ribs. Commissural (septal) suture and dorsal veins are protruding. The capsule dehisces completely by three slits, but the valves remain connected in the apical part and at the base. The capsule of $I$. hungarica is oblong-ellipsoidal, without apical spout. The surface is veined, grumous, with six grooves above the commissural sutures and dorsal veins, without ribs. The capsule of I. hungarica opens only partly toward the peduncle, leaving the lower part indehiscent. The upper parts of the valves diverge, while the lower part of the capsule remains unopened.

Conclusions. It was found that the shape of the capsule, in particular structure of its upper part, presence of ribs, and apical spout, as well as the surface features together with peculiarities of dehiscence, are constant parameters and can be used as diagnostic characters to distinguish these species. The size and color of the capsules, as well as the number of seeds per capsule of I. halophila, I. pumila and I. hungarica varied, which should be analyzed precisely in future. 


\section{Introduction}

Representatives of the genus Iris L. (Iridaceae Juss.) are ornamental herbaceous plants characterized by significant species diversity and grow in many botanical gardens and arboretums in Ukraine (Mashkovska, 2015; Gritsenko, 2018). Iris halophila Pall., I. pumila L., and I. hungarica Waldst. et Kit. are rare steppe species protected at regional level in different areas of Ukraine (Andrienko \& Peregrym, 2012). I. halophila belongs to the subgenus Xyridion (Tausch) Fourr., I. pumila and I. hungarica - to the subgenus Iris. Fruits of these species were partly investigated by Fomin \& Bordzilovsky (1950). So far, Dykes (1913) investigated principal ways of fruit dehiscence in the genus Iris. Later Rodionenko (1961) investigated the relation of the fruit dehiscence to the phylogeny of main systematic groups in the genus.

The peculiarities of fruits and seeds in some other Iris species were also sporadically investigated (Abramova \& Kryukova, 2013; Skrypec \& Odintsova, 2015; Minjal \& Boldyrev, 2016; Biryukova et al., 2018). Minjal \& Boldyrev (2017) also successfully applied the features of seeds in the development of the identification keys of Iris species.

Shvets (2006) was engaged in the study of biological peculiarities and fruit morphology of 14 Iris species (including I. halophila, I. pumila L., and I. hungarica) in connection with the introduction in the condition of the National Arboretum Sofiyivka located in Right-Bank part of the Forest-Steppe zone of Ukraine. The plants studied by Shvets were grown with the application of weeding and irrigation technologies. While in our study, plants were grown in the composition of meadow-steppe cultural phytocenosis, which is characterized by considerable phytodiversity (Gritsenko, 2017a). In our case, the conditions of Iris introduction were close to the natural, and were characterized by strong competition with other plant species, without additional weeding and watering.

In total, four rare steppe species of the genus Iris (I. halophila, I. pumila, I. hungarica, and I. graminea L.) are introduced on botanicalgeographical plot "Steppes of Ukraine" of the M.M. Gryshko National Botanical Garden, National Academy of Sciences of Ukraine (NBG). I. pumila and I. hungarica exist here within natural ranges, while I. halophila and I. graminea - outside.

In the previous studies, I examined the sozological characteristics, historical aspects of the introduction, the number, and the condition of the populations of the introduced species of the genus Iris (Gritsenko, 2005, $2012,2019 b)$. In recent years, the success of the introduction of rare Iris species in the meadow-steppe cultural phytocenosis has been evaluated, and preliminary analysis of the fruit morphology was provided (Gritsenko, 2017b, 2019a).

Mature and dry Iris fruits are little visible among the grasses and often overlooked. Moreover, the identification of dry fruits of Iris species is challenging, especially taking into account incomplete descriptions for the plants introduced in the conditions of meadow-steppe. There is a strong practical need to distinguish the fruits of Iris species by morphological peculiarities for purposes of introduction. Hence, my objective was to analyze the morphological structure of the fruits of I. halophila, I. pumila, and I. hungarica and to reveal common and distinguishing morphological features, which can be used for identification of these plants in meadowsteppe cultural phytocenoses.

\section{Material and methods}

The studies were conducted in 2015-2019 at the botanical-geographical plot "Steppes of Ukraine" of the NBG. Fruiting was observed in all four Iris species. I. halophila, I. pumila, and I. hungarica formed well-developed fruits that were included in the current investigation (Fig. $1 \mathrm{~A}-\mathrm{C}$ ). However, I. graminea produced only undeveloped fruits, which stoped or lingered in their growth and development, and dried out prematurely. Therefore fruits of I. graminea were excluded from the analysis.

To evaluate the morphological features of the fruits, 30 samples of each species were collected and investigated under $\times 2.0$ optical lens. Fruit diameters were measured in the middle part before dehiscence. All parameters were measured using a regular ruler and, hence, rounded with a precision of $1 \mathrm{~mm}$. Tables represent the arithmetic means calculated following Lakin (1990). Deviations of the author's original data from the data 

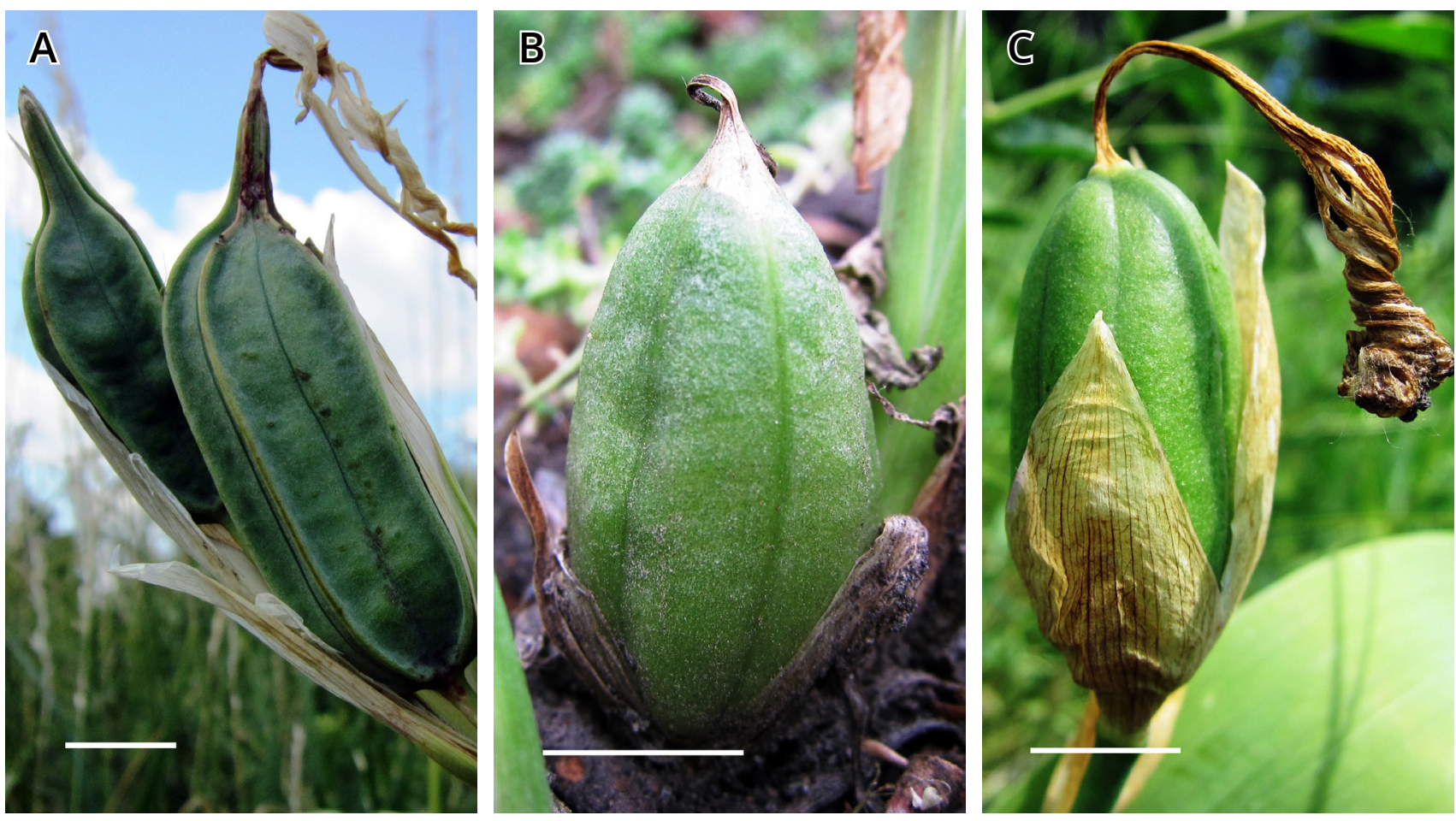

Figure 1. Unripe fruits of Iris halophila (A), I. pumila (B), and I. hungarica (C). Scale $=1 \mathrm{~cm}$.

published in the literature were calculated by following formulae: $D e v=100-y \times 100 / x$, where $\mathrm{x}$ - author's data, $\mathrm{y}$ - literature data.

Morphological terms are given accordingly to Artyushenko \& Fedorov (1986). Colors were determined and named following the Bondartsev's (1954) scale, which the best reflects the natural colors of the fruits. Plant names are provided according to The Plant List (2020). Species were determined according to the Prokudin (1987).

All photos were captured by the author using a Canon Power Shot SD 4000 IS Digital ELPH camera.

\section{Results}

Common features of Iris halophila, I. pumila, and $I$. hungarica capsules

Genus Iris is characterized by a syncarpous capsule composed of three fused carpels (Fig. 1). In the place of fused edges of carpels is formed a commissural (septal) suture. Along a midrib of each carpel, a carinal or dorsal groove is formed.

Investigated capsules are straight and erect, epigynous, three-membered, trimeric, trilocular with numerous anatropic ovules per each locule. The pericarp is coriaceous with a glabrous surface.
Capsules were dehiscing longitudinally along the carinal grooves (i.e., along the dorsal vein of each carpel) in the direction from top to bottom, and therefore are belonging to the loculicidal type.

\section{Morphological peculiarities of Iris halophila capsules}

Size: capsules are 3.5-4.8 cm long, $1.6-1.8 \mathrm{~cm}$ in diameter (Fig. 2 A-D). Shape: cylindrical (Fig. 1 A; Fig. 2 A, B). After opening, they become wineglass-shape (Fig. 2 C, D). The upper part of the capsule: elongated into a long apical spout $(0.6-1.0 \mathrm{~cm})$, which is thin, slightly bent to the side (Fig. 2 A). Surface: smooth, with veins, matte (Fig. 2 A-D). As the capsule matures, a slight whitish plaque is observed. The capsule has six sharp and well-expressed ribs located along both sides of dorsal grooves (Fig. 2 A-B). Peduncle: $3.0-4.8 \mathrm{~cm}$ long, almost as long as the capsule.

Dehiscence: complete (Fig. 2 C) or almost complete (Fig. 2 D). As the capsule matures and opens, the upper parts of the valves diverge and bend, but near the base, the valves remain connected (Fig. 2 D).

Color: unripe capsules have a color of darkgreen grass; colors of ribs are lighter - of green grass. The color of ripe capsules differs in different parts: along the commissural sutures, 

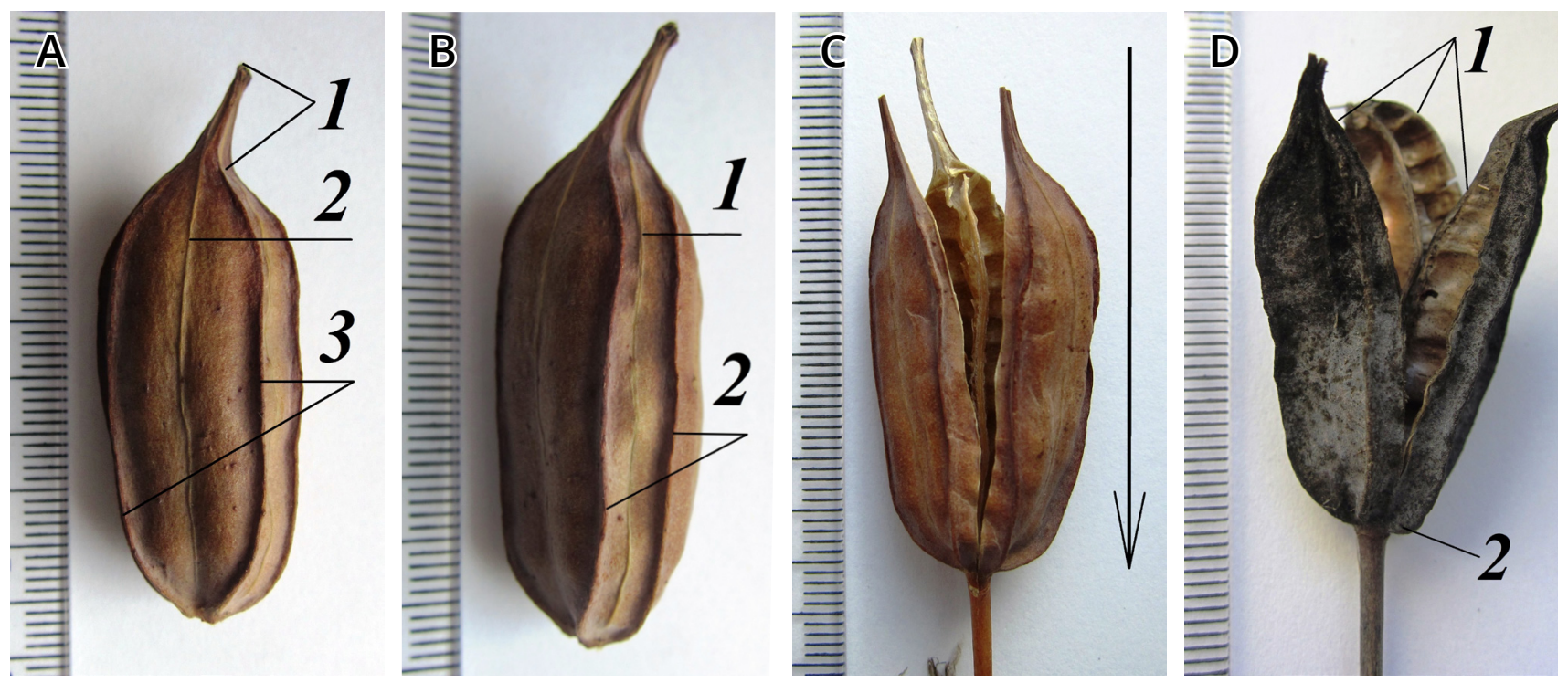

Figure 2. Morphological peculiarities of Iris halophila capsules: A - apical spout (1), commissural suture (2), ribs (3); B - carinal groove (1) and ribs (2); C - degree, and direction of the dehiscence (arrow); D - upper parts of the valves (1) and fruit base (2).


Figure 3. Morphological peculiarities of Iris pumila capsules: A - apical spout (1), commissural suture (2), edges of a dehisced carinal groove (3); B - degree and direction of the dehisce (arrow); C - dehiscence of the capsule by slits; D - valves edges along the slits (1), fruit base (2).

they are lighter - dark-sandy, and closer to the ribs, they become darker - pale-brown. The color of the ribs is even more intense - a dirtybrown-purple. In the autumn, the capsules become of dark-chestnut color; a whitish plaque on the valves becomes more noticeable (Fig. 2 D). According to Shvets (2006) the color of I. halophila fruits is brown.

Fruiting: regular, annual. The capsules ripe in late August. Over time they become darker (Fig. 2 D) and remain in the meadowsteppe cultural phytocenosis for a long time (with seed residues), without collapsing until November. Generally, 2-3 capsules are formed on the generative shoot. There are 40-60 seeds developing per capsule.

\section{Morphological peculiarities of Iris pumila capsules}

Size: capsules are $2.5-4.0 \mathrm{~cm}$ long, $1.5-1.7 \mathrm{~cm}$ in diameter (Fig. 3 A, B, D). According to Fomin \& Bordzilovsky (1950), capsule length is higher, 4.0-6.0 cm. Shape: ellipsoidal; the length of 

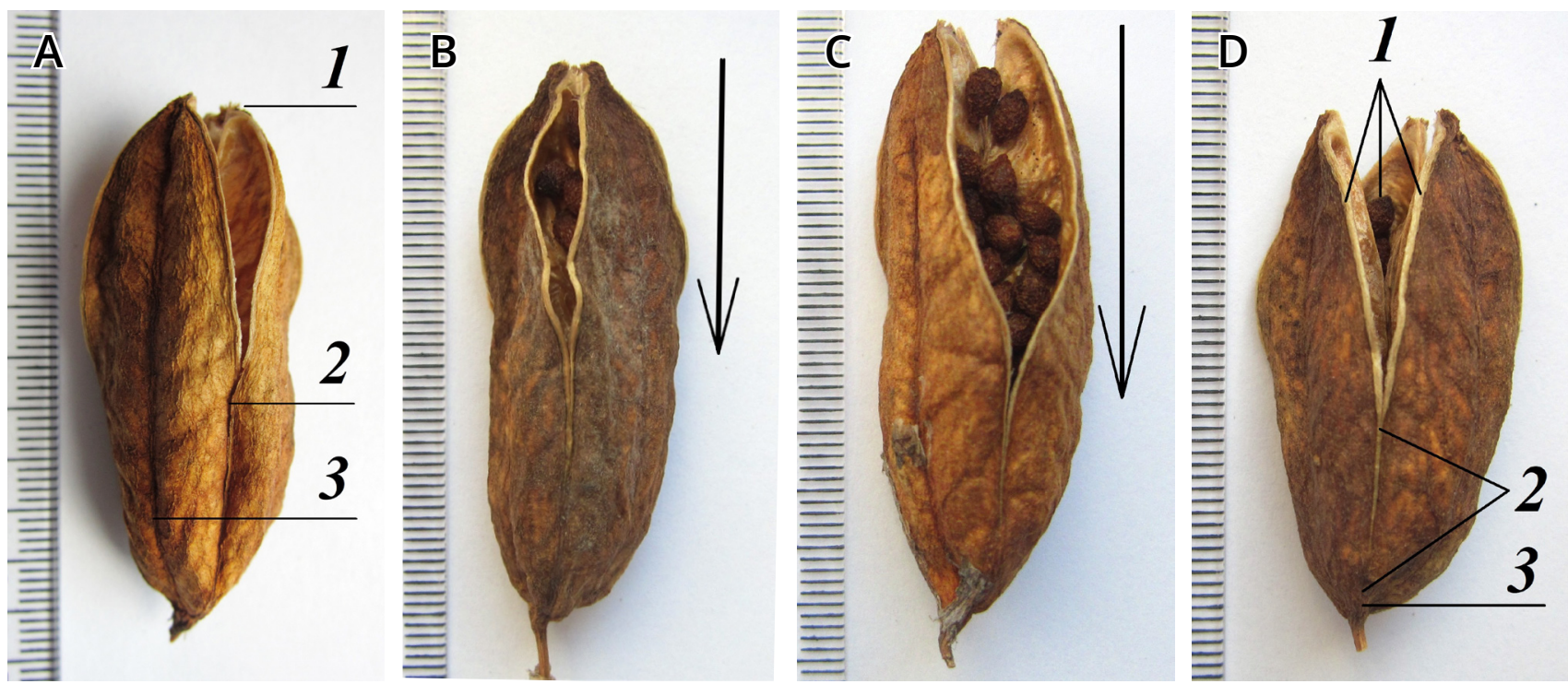

Figure 4. Morphological peculiarities of Iris hungarica capsules: A - upper part of the capsule (1), carinal groove (2), and commissural suture (3); B, C - degree, and direction of the dehiscence (arrow); D - upper (1) and lower (2) parts of the valves, and fruit base (3).

the valves exceeds the width in 1.5-2 times. The shape of unripe and almost ripe capsules is indistinctly trihedral (Fig. 1 B; Fig. 3 C). After opening and exsiccation, the capsules become slightly deformed (Fig. 3 A, B, D). The upper part of the capsule: elongated into the apical spout, which is short $(0.4-0.5 \mathrm{~cm})$, thick, awlshaped (Fig. 3 A). Surface: wrinkled, wrinkles oriented from the commissural suture (Fig. $3 \mathrm{~A}$ ) obliquely upwards to the carinal suture (Fig. 3 A). All sutures are well pronounced, protruding (Fig. $3 \mathrm{~A}-\mathrm{D})$. The capsule surface is without ribs. Peduncle: very short $(0.2-0.3 \mathrm{~cm}$; Fig. 1 B; Fig. 3 C).

Dehiscence: complete (Fig. 3). Capsule dehisces by three slits (Fig. 3 C), which gradually open. The edges of the valves along the slits diverge and invert outwards (Fig. 3 D). Valves of the capsule remain connected at the apex and at the base (Fig. 3 D).

Color: unripe capsules are color of green grass; the color of the sutures is more intense - like dark-green grass. When capsules mature, their color varies from yellow-green to yellow-brown. According to Shvets (2006), the color of I. pumila fruits is almost black.

Fruiting: irregular, every few years. The capsules ripe in late July and are quickly destroyed. A single capsule is formed on the generative shoot just near the level of the soil surface. There are 35-45 seeds per capsule. In the Bashkortostan Republic, the number of seeds per fruit in I. pumila in natural conditions can vary from 10 to 42 , and in the conditions of introduction - from 26 to 52 (Abramova \& Kryukova, 2013).

\section{Morphological peculiarities of Iris hungarica capsules}

Size: capsules are $3.5-5.2 \mathrm{~cm}$ long, $1.4-1.8 \mathrm{~cm}$ in diameter (Fig. 4 A-D). Shape: oblong-ellipsoidal (Fig. $1 \mathrm{C}$; Fig. 4 A-C). When opened, the capsules can take the shape of a wineglass (Fig. 4 D). The upper part of the capsule: without apical spout (Fig. 4 A); in shape, resembles a truncated cone (Fig. 4 B). Surface: veined; veins clearly expressed, branched. As the capsules mature, the surface becomes grumous. The surface has six shallow longitudinal grooves above the carinal grooves and commissural sutures (Fig. 4 A). The capsule surface is without ribs. Peduncle: short $(0.6-1.1 \mathrm{~cm})$.

Dehiscence: capsule dehisces to half (Fig. 4 B) or a little more (Fig. 4 C). When the capsule opens, the upper parts of the valves diverge (Fig. 4 D), but lower parts of the valves remain connected in almost $1 / 3$ of the capsule's length (Fig. 4 D).

Color: unripe capsules have a color of green grass. When capsules mature, their color varies from lighter (yellow-brown) to darker (pale-brown). According to Shvets (2006), the color of I. hungarica fruits is light-reddish.

Fruiting: regular, every year. Fruits ripe in August. Usually, 1-2 capsules are formed on 
Table 1. Comparison of the morphological parameters of capsules in Iris halophila, I. pumila, and I. hungarica introduced in Ukraine (original data with those reported by Shvets, 2006).

\begin{tabular}{|c|c|c|c|c|c|c|c|c|c|}
\hline \multirow{2}{*}{ Species } & \multicolumn{2}{|c|}{$\begin{array}{l}\text { Capsule length, } \\
\mathrm{cm}\end{array}$} & \multirow{2}{*}{ 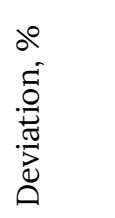 } & \multicolumn{2}{|c|}{$\begin{array}{l}\text { Capsule diameter, } \\
\mathrm{cm}\end{array}$} & \multirow{2}{*}{ 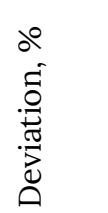 } & \multicolumn{2}{|c|}{$\begin{array}{l}\text { Number of seeds per } \\
\text { capsule }\end{array}$} & \multirow{2}{*}{ 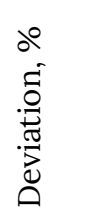 } \\
\hline & $\begin{array}{l}\text { Original } \\
\text { data }\end{array}$ & $\begin{array}{l}\text { Reported } \\
\text { data }\end{array}$ & & $\begin{array}{l}\text { Original } \\
\text { data }\end{array}$ & $\begin{array}{l}\text { Reported } \\
\text { data }\end{array}$ & & $\begin{array}{l}\text { Original } \\
\text { data }\end{array}$ & $\begin{array}{l}\text { Reported } \\
\text { data }\end{array}$ & \\
\hline I. halophila & 4.00 & 3.54 & +11.50 & 1.70 & 1.75 & -2.94 & 47 & 40 & +14.89 \\
\hline I. pumila & 3.90 & 4.53 & -16.15 & 1.50 & 1.25 & +16.67 & 40 & 43 & -7.50 \\
\hline I. hungarica & 4.80 & 5.52 & -15.00 & 1.60 & 1.65 & -3.12 & 50 & 49 & +2.00 \\
\hline
\end{tabular}

each generative shoot. There are $45-55$ seeds per every single capsule.

\section{Exceptional cases}

Exceptional cases of the morphological structure of Iris capsules were observed. During the studies, we observed one-time cases of bicarpelar dimeric (bilocular) capsules in I. halophila and I. hungarica. However, the overall shape and other morphological peculiarities in such mutated fruits were still similar to regular ones.

\section{Discussion}

In the conditions of introduction in the meadow-steppe cultural phytocenosis reconstructed at the NBG experimental plot, the indices of the sizes of capsules I. halophila, I. pumila, and I. hungarica, as well as the number of seeds per capsule were compatible to those reported before, but with a significantly lower level of deviation (Tables 1 $\& 2$ ). The variations of these indicators in Ukraine were in the range from $-16.15 \%$ to $+16.67 \%$ (Table 1), while in other regions of the temperate zone of Eurasia, they ranged from $-46.67 \%$ to $+35.00 \%$. We also found that our observations differed from colors reported for I. halophila, I. pumila, and I. hungarica by Shvets (2006). Thus, the size and color of the capsules, as well as the number of seeds per capsule in I. halophila, I. pumila, and I. hungarica capsules differed, what may depend on environmental conditions, geographical location or other factors, which were not revealed during this research. From the other side, general shape of capsule, the shape of its upper part, surface structure, as well as degree and dehiscence type seem to be stable parameters that can be applied for distinguishing these three species. However, for the final conclusion, more investigations within different habitats and with a higher number of samples are required.

\section{Conclusions}

The common and distinguishing morphological parameters of the capsules of I. halophila, I. pumila, and I. hungarica were revealed. The shape of the upper part of the capsule, presence of apical spout, the surface of the capsule, and peculiarities of dehiscence seem to be constant parameters and can be applied as additional diagnostic criteria of these species. Size and color of the capsule and the number of seeds per capsule varied for I. halophila, I. pumila, and I. hungarica, and should be analyzed precisely in future.

\section{References}

Abramova L. M., \& Kryukova, A. V. (2013). Rare Iris pumila L. species seed productivity in nature and in the introduction. Bulletin of Orenburg State University, 10(159), 156-159. (In Russian)

Andrienko, T. L., \& Peregrym, M. M. (2012). Official lists of regionally rare plants of the administrative territories of Ukraine (reference edition). Kyiv: Alterpress. (In Ukrainian)

Artyushenko, Z. T., \& Fedorov, A. A. (1986). Atlas on the descriptive morphology of higher plants. Fruit. Leningrad: Science. (In Russian)

Biryukova, O. A., Kuklina, K. E., Grinchenko, K. V., Zaitseva, D. M., \& Kurshakova, E. I. (2018). Fruits indicators of Xyridion irises in the Mari El republic conditions. International Journal of Humanities and Natural Sciences, 10-1, 121-124. (In Russian) 
Table 2. Comparison of the morphological parameters of capsules in Iris halophila and I. pumila growing in and outside of Ukraine.

\begin{tabular}{|c|c|c|c|c|c|c|c|c|c|}
\hline \multirow{2}{*}{ Species } & \multicolumn{2}{|c|}{$\begin{array}{l}\text { Capsule length, } \\
\mathrm{cm}\end{array}$} & \multirow{2}{*}{ 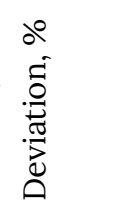 } & \multicolumn{2}{|c|}{$\begin{array}{l}\text { Capsule diameter, } \\
\mathrm{cm}\end{array}$} & \multirow{2}{*}{ 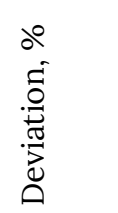 } & \multicolumn{2}{|c|}{$\begin{array}{l}\text { Number of seeds per } \\
\text { capsule }\end{array}$} & \multirow{2}{*}{ 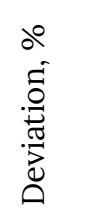 } \\
\hline & $\begin{array}{l}\text { Original } \\
\text { data }\end{array}$ & $\begin{array}{l}\text { Reported } \\
\text { data }\end{array}$ & & $\begin{array}{l}\text { Original } \\
\text { data }\end{array}$ & $\begin{array}{l}\text { Reported } \\
\text { data }\end{array}$ & & $\begin{array}{l}\text { Original } \\
\text { data }\end{array}$ & $\begin{array}{l}\text { Reported } \\
\text { data }\end{array}$ & \\
\hline I. halophila & 4.00 & 5.14 & -25.00 & 1.70 & 1.86 & -9.41 & 47 & 53 & -12.77 \\
\hline \multirow[t]{2}{*}{ I. pumila } & 3.90 & 5.25 & -34.62 & 1.50 & 2.00 & -33.33 & 40 & 26 & +35.00 \\
\hline & & 5.30 & -35.90 & & 2.20 & -46.67 & & 39 & +2.50 \\
\hline
\end{tabular}

Note: Reported data for Iris halophila - Mari El Republic, plants in culture (Biryukova et al., 2018). Reported data for I. pumila - Bashkortostan republic (Abramova \& Kryukova, 2013). For I. pumila the upper indicator is for plants growing in nature, and the lower indicator is for plants growing in culture.

Bondartsev, A. S. (1954). The scale of colors. A manual for biologists in scientific and applied research. Moscow: Publishing House of the Academy of Sciences of the USSR. (In Russian)

Dykes, W. R. (1913). The genus Iris. Cambridge University Press.

Fomin, O. V., \& Bordzilovsky, E. I. (1950). Family Irysovi - Iridaceae Lindl. In M. I. Kotov (Ed.), Flora of the UkrSSR. Vol. 3 (pp. 276-312). Kyiv: Edition of the Academy of Sciences of the UkrSSR. (In Ukrainian)

Gritsenko, V. V. (2005). Introductive populations of plants in the meadow-steppes of culturphytocoenoses. Plant Introduction, 25(1), 17-22. (In Ukrainian). https://doi.org/10.5281/ zenodo. 2586143

Gritsenko, V. V. (2012). Rare species of plants in steppe culturphytocoenose: The systematic composition, sozological characteristic, the historical aspects of the introduction, the contemporary state. Plant Introduction, 54(2), 13-21. (In Ukrainian). https://doi.org/10.5281/ zenodo.2541996

Gritsenko, V. V. (2017a). Phytodiversity of the botanical-geographical section "Steppes of Ukraine" in the National Botanical Garden N. N. Grishko NAS of Ukraine. Forestry and gardening, 12, 9558. (In Ukrainian). Retrieved from http:// journals.nubip.edu.ua/index.php/Lis/article/ view/9558/

Gritsenko, V. V. (2017b, September 19-21). The modern state and assessment of the success of the introduction of rare species of the genus Iris L. (Iridaceae) in meadow-steppe culture phytocenosis. In The collection of articles of the International scientific conference "The gene pool of collections of botanical gardens and arboretums is a pledge of stable phytocoenoses in conditions of climate change (pp. 150-153). Odesa: I.I. Mechnikov Odesa National University. (In Ukrainian).
Gritsenko, V. V. (2018, June 12-15). Decorative beautifully flowering plants in the phytodiversity of meadow-steppe culturhytocenosis. In Proceedings of the $10^{\text {th }}$ International Scientific Conference "Landscape architecture in botanical gardens and arboretums" (pp. 270-274). Kamianets-Podilskyi: FOP Sysin O. V. (In Ukrainian).

Gritsenko, V. V. (2019a). Evaluation of success of introduction of rare species of plants in the meadow-steppe culturphytocenosis. Plant Introduction, 82(2), 24-33. (In Ukrainian). https:// doi.org/10.5281/zenodo.3241019

Gritsenko, V. V. (2019b). Historical analysis of plant introduction and scientific activity: To the $70^{\text {th }}$ anniversary of the botanical and geographical plot "Steppes of Ukraine" in M.M. Gryshko National Botanical Garden of the NAS of Ukraine. Plant Introduction, 83(3), 3-13. (In Ukrainian). https://doi.org/10.5281/zenodo.3404098

Lakin, G. F. (1990). Biometrics. Moscow: Higher School. (In Russian)

Mashkovska, S. P. (Ed.). (2015). Catalog of ornamental herbaceous plants of botanical gardens and arboretums of Ukraine: A reference guide. Kyiv. (In Ukrainian). Retrieved from www.nbg.kiev.ua/ upload/biblio/katalog.pdf

Minjal, M. S., \& Boldyrev, V. A. (2016). Morphometric characters of seeds of some species of the genus Iris L. in Saratov region. News of Saratov University. New Series. Ser. Chemistry, Biology, Ecology, 16(4), 404-410. (In Russian). https://doi. org/10.18500/1816-9775-2016-16-4-404-410

Minjal, M. S., \& Boldyrev, V. A. (2017). Identification key by seed of Iris L. species in Saratov region. Scientific Almanac. Biological sciences, 10-2(36), 227-229. (In Russian).

Prokudin, Y.N. (Ed.). (1987). Key to higher plants of Ukraine. Kyiv: Naukova Dumka. (In Russian) 
Rodionenko, G. I. (1961). Genus Iris - Iris L.: Questions of morphology, biology, evolution and systematics. Moscow - Leningrad: Publishing House of the Academy of Sciences of the USSR. (In Russian)

Shvets, T. A. (2006). Biological peculiarities of the species of the genus Iris $L$. in connection with the introduction in condition of the Right Bank partially of the Forest-Steppe Zone of Ukraine (Candidate dissertation). Kyiv. (In Ukrainian)
Skrypec, C. I., \& Odintsova, A. V. (2015). Fruit and seed morphology in Iris sibirica L. and Gladiolus imbricatus L. in relation with the modes of dissemination. Biological systems, 7(1), 93-96. (In Ukrainian)

The Plant List. (2020). Retrieved from http://www. theplantlist.org/

\title{
Морфологічні особливості плодів рідкісних видів Iris halophila Pall., I. pumila L., I. hungarica Waldst. et Kit. (Iridaceae Juss.) в умовах інтродукції у лучно-степовому культурфітоценозі
}

\author{
В.В. Гриценко
}

Національний ботанічний сад імені М.М. Гришка НАН України, вул. Тімірязєвська, 1, м. Київ, 01014, Україна; gritsenkoviktoria@gmail.com

Мета -проаналізувати морфологічну будову плодів рідкісних степових видів Iris halophila, I. pumila та I. hungarica в умовах інтродукції в лучно-степовому культурфітоценозі; встановити морфологічні параметри спільні для плодів 1. halophila, I. pumila, I. hungarica, а також виявити морфологічні особливості плодів, які можуть бути додатковими діагностичними ознаками цих видів.

Матеріал та методи. Дослідження проводили у 2015-2019 рр. Матеріалом слугували плоди I. halophila, I. pumila та I. hungarica, зібрані у Національному ботанічному саду імені М.М. Гришка НАН України на ботаніко-географічній ділянці “Степи України”. Морфологічні терміни наведено згідно 3 3.Т. Артюшенко та О.О. Федоровим.

Результати. У всіх досліджених видів плід - локуліцидна, тричленна, тримірна, тригнізда, багатонасінна, прямостояча, пряма, шкіряста, гола, розкривна зверху вниз по стулкам вздовж дорзальних жилок плодолистків коробочка. Однак, було виявлено морфологічні особливості плодів, які можуть бути додатковими діагностичними ознаками цих видів. Зокрема, коробочки 1. halophila циліндричні. Верхня частина коробочки видовжена в апікальний носик (довгий, тонкий, відігнутий у бік). Поверхня гладка, матова, шести-ребриста. Ребра попарно зближені по обидва боки від дорзальних жилок. Коробочка розкривна повністю. Верхні частини стулок розходяться, при основі стулки з'єднані. Коробочки I. puтila еліпсоїдальні. Верхня частина коробочки видовжена в апікальний носик (короткий, товстий, шиловидний). Поверхня зморшкувата, без ребер. Комісуральні (септальні) шви та дорзальні жилки виступаючі. Коробочка розкривна повністю. Розкривається трьома щілинами; стулки коробочки з'єднані в апікальній частині та при основі. Коробочки I. hungarica продовгувато-еліпсоїдальні. Верхня частина коробочки без апікального носика. Поверхня жилкувата, горбиста, з шістьма борозенками вздовж дорзальних жилок плодолистків і септальних перегородок, без ребер. Коробочка розкривна до половини. Верхні частини стулок розходяться, у нижній частині коробочки та при основі стулки залишаються сполучені.

Висновки. Встановлено, що морфологічні особливості форми, верхньої частини коробочок, апікального носика (або його відсутність), поверхні коробочок, особливості швів, розташування ребер (або їх відсутність), а також ступінь та особливості розкриття коробочок $\epsilon$ константними параметрами і можуть використовуватись, як додаткові діагностичні ознаки I. halophila, I. pumila та 1. hungarica. 3'ясовано, що розміри і колір коробочок, а також кількість насінини в коробочках цих видів відрізняються, що потребує детальнішого вивчення. 